\title{
Bioethics of Organ Transplantation
}

\author{
Arthur Caplan \\ Division of Medical Ethics, NYU Langone Medical Center, New York, New York 10016 \\ Correspondence: arthur.caplan@nyumc.org
}

As the ability to transplant organs and tissues has grown, the demand for these procedures has increased as well — to the point at which it far exceeds the available supply creating the core ethical challenge for transplantation-rationing. The gap between supply and demand, although large, is worse than it appears to be. There are two key steps to gaining access to a transplant. First, one must gain access to a transplant center. Then, those waiting need to be selected for a transplant. Many potential recipients do not get admitted to a program. They are deemed too old, not of the right nationality, not appropriate for transplant as a result of severe mental impairment, criminal history, drug abuse, or simply because they do not have access to a competent primary care physician who can refer them to a transplant program. There are also financial obstacles to access to transplant waiting lists in the United States and other nations. In many poor nations, those needing transplants simply die because there is no capacity or a very limited capacity to perform transplants. Although the demand for organs now exceeds the supply, resulting in rationing, the size of waiting lists would quickly expand were there to suddenly be an equally large expansion in the number of organs available for transplantation. Still, even with the reality of unavoidable rationing, saving more lives by increasing organ supply is a moral good. Current public policies for obtaining organs from cadavers are not adequate in that they do not produce the number of organs that public polls of persons in the United States indicate people are willing to donate.

\section{PRESENT POLICIES REGARDING ORGAN PROCUREMENT ARE INADEQUATE}

W hy does the supply of organs lag behind demand? There are many reasons for believing that current systems of organ procurement are not as efficient as they could be in obtaining organs from cadaver sources. In the United States, the prevailing public policy is one of "encouraged voluntarism." This policy was established when states began adopting the Uniform Anatomical Gift Act in 1968 (Caplan 1984; DeVita and Caplan 2007). The United
States as well as Canada, the United Kingdom, Denmark, Australia, and many other nations rely on altruistic donation reinforced by ongoing public education campaigns. In the case of Israel and Singapore, priority in access to transplants is an additional incentive to be a donor (Chandler 2005; Quigley et al. 2012). Individuals may use donor cards to make their wish to donate all or some organs known after their death. In some parts of the world and many states in the United States, computer registries facilitate organ donation.

Editors: Laurence A. Turka and Kathryn J. Wood

Additional Perspectives on Transplantation available at www.perspectivesinmedicine.org

Copyright (C) 2014 Cold Spring Harbor Laboratory Press; all rights reserved; doi: 10.1101/cshperspect.a015685

Cite this article as Cold Spring Harb Perspect Med 2014;4:a015685 
A. Caplan

Public surveys show support for organ donation in the United States at levels not reflected in actual donor rates (www.mayoclinic .org/news2013-rst/7428.html). Many organ donors are not identified as such at the time of death by healthcare personnel. Although families in the United States do not have the legal standing to veto a signed request to donate by a deceased relative, in practice they are almost always accorded that right.

\section{WHY HAS "ENCOURAGED VOLUNTARISM" FALLEN SHORT?}

There are many reasons why the policy of encouraged voluntarism has not produced as many organs for transplant as might be expected. Many people still do not carry a donor card or other written directive specifying the disposition of their bodies when they die. Often people do not discuss their wish to donate with their family, partners, or friends. Rates of donation among the poor are low. Computer registries help but they are no substitute for discussions about donation before death. Many people are loath to contemplate their own death, much less make plans for the disposition of their bodies. This means that many people are not going to fill out a donor card just as they are not going to make out a will, buy a funeral plot, or complete an advance directive concerning the kind of medical care they would like to have if they become incompetent (Caplan 1984).

The fact that health care has in recent years become increasingly centralized in large and impersonal institutions undermines trust between patients and healthcare providers. It is very difficult to trust in the good intentions of strangers. Some people are afraid that if they carry a donor card they may not receive aggressive medical care if they need it so that others can be given their organs. Still others believe that only the rich can get transplants and so see no reason to act as donors.

The failure to secure higher rates of compliance with respect to written directives and the mistrust of hospitals and healthcare providers are, however, only part of the explanation for low rates of organ procurement. The reality in the United States, Canada, Germany, the United Kingdom, and many other nations is that when the subject of donation is raised it is done with the presumption that the family of the deceased must decide to opt into donation. It may be possible to obtain a higher rate of donation simply by changing the philosophy underlying requests to donate from an "opt in" approach to an "opt out" approach (Caplan 2013). Still other nations such as China are willing to execute "prisoners" to obtain a steady supply of organs-a grossly unethical approach to obtaining organs (Wang 2010; Caplan et al. 2012). There is some enthusiasm for using markets to increase the cadaver supply (Davis and Crowe 2009; Hughes 2009; Kerstein 2009; Taylor 2009; Lawlor 2011; Jaycox 2012; Slabbert 2012).

\section{GETTING MORE ORGANS-MARKETS?}

Two basic strategies have been proposed to provide incentives for people to sell their organs when they die. One strategy is simply to permit organ sale in the United States by changing the National Organ Transplant Act (NOTA), the 1986 federal law that bans organ sales. Then, individuals would be free to broker contracts with persons interested in selling at prices mutually agreed on by both parties (Lawlor 2011; Slabbert 2012). The other strategy is to create a regulated market in which the government would act as the purchaser of organs-setting a fixed price and enforcing conditions of sale (Matas 2006; Lawlor 2011). Both proposals have drawn heated ethical criticism.

Would markets really work in the United States or other economically advanced nations to increase organ supply? It is hard to imagine many people in wealthy countries eager to sell their organs upon their death who do not now donate them. In fact, even if compensation is relatively high, few will agree to sell. Polls show that the disincentive to cadaver donation has more to do with aesthetic, emotional, or religious concerns than a lack of payment. That has been the experience with markets in human eggs for research purposes and paid surrogacy in the United States with prices escalating through the roof and still relatively few sellers. If 
there is already a fear of premature pronouncement of death to obtain organs, enacting market incentives for cadaver donation is likely to exacerbate this fear (DeVita and Caplan 2007).

Perhaps living persons can be induced to sell nonvital organs. In fact, the United States now obtains more kidneys for transplant from those who donate a kidney to a friend or a family member than from cadaver sources. However, markets that incentivize living persons have their own ethical problems.

One problem is that only kidneys are likely to be available in a living seller market. Hearts will obviously not be. Lungs and liver involve such risky procurement surgery that they are not likely to attract sellers. Another moral challenge is that only the poor and very desperate will want to sell their body parts. If you need money, you might sell your kidney to try and feed your family or to pay back a debt. This may be a "rational" decision, but that does not make it a matter of free choice. Watching your child go hungry while you lack a job and a wealthy person waves a wad of bills in your face is not exactly a scenario that inspires confidence in the valid choices that the poor would make in a market for body parts. Talk of individual rights and autonomy is hollow if those with no options must "choose" to sell their organs to purchase life's necessities (Caplan and Prior 2009; Kerstein 2009; Taylor 2009; Lawlor 2011; Jaycox 2012). Choice requires options as well as information and some degree of freedom.

Major religious traditions oppose payment on the grounds that persons do not own but are, rather, the stewards of their bodies (Caplan and Prior 2009; Caplan 2013). Payment also introduces risks concerning the quality of organs obtained. And payment may give persons an inducement to kill or take organs from others to pay debts.

Another very important ethical challenge to proposals to permit markets is that selling organs, even in a tightly regulated market, violates the ethics of medicine. The core ethical norm of the medical profession is the principle "do no harm." The only morally defensible way to remove an organ from someone is if the donor chooses to undergo the harm of surgery solely to help another, and if there is sufficient medical benefit to the recipient. The creation of a market puts medicine and nursing in the position of removing body parts from people solely to abet those people's interest in securing compensation (Caplan 2004, 2013). In a market, even a regulated one, doctors and nurses would be using their skills to help people harm themselves for money. The resulting distrust and loss of professional standing may be too high a price to pay for a gamble that a market in living sellers may secure more organs (Tan et al. 2008).

\section{DEFAULT TO DONATION}

If public opinion surveys can be trusted, most Americans are willing to serve as a donor when they die. The problem is that "encouraged voluntarism" using donor cards does not seem to be able to fully tap this powerful sentiment. There is another way of modifying existing practice that would respect the dignity and value of individual choice while at the same time holding out the prospect of increasing the number of organs obtained from cadaver sources. It requires a shift in the ethical presumptions that prevail about organ donation.

If public policy were to be modified to a default that presumes that people do want to be donors, this might have a positive impact on donation rates. Some nations, such as France, Austria, Belgium, and Spain, have legislated versions of presumed consent with a consequent positive impact on their cadaver donor rates (Abadie and Gay 2006; Byk 2009; Neades 2009).

A policy of default to donation addresses many of the failings of the current approach to cadaver organ procurement. It allows opting out of cadaver donation while allowing the view of the majority toward donation to set policy.

There are two main worries about shifting to a default to donation policy in the United States, United Kingdom, Canada, and other nations. One is that forcing a choice will lead to many more people opting out than currently do. This has not been seen in nations with default to donation policies. The other is simple resistance to the shift toward donation for fear that objections will not be accurately tracked. 
A. Caplan

The increasing use of computer registries may help buffer this concern.

\section{TOUGHENING "ENCOURAGED VOLUNTARISM" - CHARITY TO OBLIGATION?}

For many years, the rhetoric in educating the public has emphasized charity. People are constantly being urged through public service advertisements in magazines, in newspapers, and on radio and television to "make the gift of life." What is interesting about "gift" to urge organ donation is that the moral force of such language is not particularly strong. Gifts are a form of charity. Most moral theories recognize a strong moral obligation or duty not to harm others. But few theories posit the existence of an obligation or duty to give gifts to other people. Gift-giving behavior is viewed as morally laudable, but it is not often seen as mandatory.

The question raised by using "gift" in this context is whether society really wants to view organ donation in this way. One answer to this question is to examine the ways in which positive obligations, or duties, to aid other people are usually generated. Some duties to help others arise as a result of particular roles or jobs in society. Firefighters, parents, and nurses all have special duties to render positive aid to others even when helping requires sacrifice and even risk. Another way in which duties to help others can arise is through the act of contracting or promising. I can voluntarily promise to help someone else if the need should arise, and can be blamed for my failure to do so under the appropriate circumstances (Caplan and Coehlo 1998).

Neither of these arguments for positive obligations is applicable to the situation with respect to cadaver organ donation. Unless I have promised to donate an organ to another and try to renege on my promise, there would seem to be no ground for saying that I ought to be an organ donor in any sense stronger than pure charity.

There is, however, another way in which duties to help others can go beyond exceptional cases of charity or gift giving. If it is possible for someone to do a great deal of good for another person without facing the prospect of a great deal of risk or even inconvenience, and if there is a strong likelihood of benefit for the recipient, then a duty exists which is stronger than the relatively weak obligations associated with supererogatory acts. If, for example, a strong swimmer can save the life of a drowning child merely by swimming 20 feet out into a calm lake, it would seem morally reprehensible and blameworthy for the swimmer not to do so. Indeed, it would seem odd to describe such a rescue as a charitable act, heroism, or even a gift from the swimmer to the drowning child (Caplan and Coehlo 1998). Is donation after death closer to an obligation of this sort? If it is true that many can be helped by an increase in the supply of organs, and if it is also true that the dead can suffer no harm by using their tissues and organs for transplantation, then is it correct to describe a decision to donate as a gift that is praiseworthy if offered but not blameworthy if withheld or, as an obligation that is both? Unless one holds religious views about the need to try and insure an intact body postdeath, it is hard to see how the ability to help others could overcome a reluctance to donate. Perhaps, shifting the rhetoric of donation to duty rather than gift would increase the supply of cadaver organs (Veatch 2002).

\section{DEALING WITH SCARCITY - EQUITY IN TRANSPLANTATION}

The trust that is essential for public support is a product of a key ethical value-equity. The values of altruism and autonomy-the foundations of organ procurement-rest on the presumption that organs, which are given freely, voluntarily and altruistically, will be distributed in a fair and impartial manner to those in need. Any policies, practices, or activities that suggest otherwise imperil the entire enterprise of voluntary and altruistic organ donation. There is sufficient evidence of inequity in the allocation of organs to raise doubts about the fairness of the existing system. If inequity is perceived then trust is imperiled and donation will be adversely impacted. 
The ever-present news stories of families desperately seeking funds, begging for money to pay for transplants in many nations, leave an especially bitter taste in the mouths of a public that expects altruism. If organs are requested from the rich and poor alike but, given primarily to the rich, how can we expect the public to support transplantation with either organs?

An impressive number of papers have appeared in the past few years in professional journals maintaining that women, the elderly, the disabled, the retarded, and minorities are not represented in the ranks of those receiving transplants to the extent that they could and should be. Policies that give priority of access to patients on artificial heart assist devices (LVADs), or to those who require multiple organ transplants or retransplantation, leave plenty of room for doubt about what values are being used to allocate scarce organs. The tolerance of multiple listing (Sanaei Ardekani and Orlowski 2010)_-going to more than one transplant center to be wait-listed-by those who can afford to do so and thus gain access to a larger share of the organ donor pool, a strategy that Steve Jobs and Lou Reed used to obtain livers, is blatantly unfair. Explicit policies at some centers that exclude some categories of patients from the prospective recipient pool because they have a history of drug abuse (including marijuana), crime, or simply because they have a mental disability give further reason for doubt about equity in the allocation of organs.

In addition, the fact that so many hospitals and medical centers have rushed into the transplant field raises legitimate doubts about the fairness of the system for distributing organs and tissues. The competition between transplant centers to secure organs is certainly not in the public interest especially when distribution is partly based on geography and there is little unmet need for access to a center in the United States in terms of program availability. The impression that the allocation of organs is based on bias, prejudice, favoritism, greed, geography, or ability to command publicity is enough to weaken public confidence that the system is equitable. Flat rates for cadaver organ donation may reflect skepticism about the fairness for rationing what is given.

\section{IS IT FAIR TO GIVE EVERYONE IN NEED AN EQUAL CHANCE TO GET A TRANSPLANT?}

To know whether the distribution of organs in the United States is fair and equitable, it is not sufficient to look at data on who did and did not get transplanted in any given year. This information is necessary but not sufficient for evaluating the fairness of the distribution. All that any pattern of distribution proves is that there may be reason for concern about inequity. The underrepresentation of minorities, the poor, the disabled, or the elderly in the ranks of transplant recipients might be unfortunate, but it might not be unfair.

To know whether the distribution of organs is fair, it is necessary to know the pattern of need for transplants. If every person is at equal risk of end-stage organ failure, or if those who actually suffer organ failure of various kinds represent a microcosm of the overall American population or any national population, then any deviation from this average in the distribution of organs gives reason for concern about fairness.

A final assessment of the equity of the distribution of organs will depend on an examination of the criteria and rules (or lack of them) being followed by transplant centers. It might be fair to give men more organs than women or whites fewer organs than blacks if the allocation were based on a set of criteria and rules that men and women and blacks and whites could all agree are fair, even if the rules work to the disadvantage of some persons or groups (Veatch 2002).

In asking what criteria, policies, and procedures are used to allocate organs, it is tempting to seek the answer by examining what happens to a particular organ that is donated or what decisions are made on any given day in the case of a particular transplant program. But looking only at such situations conveys a very misleading impression of how allocation decisions are actually made.

The question of who gets organs is a function of numerous factors: how many transplant 
A. Caplan

programs there are, how many organ donors there are, what standards exist for evaluating the suitability of organs for transplant, how far organs and tissues can be shipped without damage, whether a person has health insurance or not, and a host of other variables. The fairness of organ allocation cannot be understood simply by watching what various surgeons or transplant centers actually do when they have the opportunity to transplant a donated organ. Transplant centers, and the surgeons who administer particular organ transplant programs within them, need to deal only with those patients who have actually made it through their doors. But many potential recipients never appear on any center's waiting list. The most important ethical decisions about allocation take place long before an organ actually arrives to be used at a particular transplant center.

\section{JUSTICE AND RATIONING SCARCE ORGANS FOR TRANSPLANTATION}

There is no consensus about what constitutes fair distribution with respect to scarce resources. There are theories of justice that would direct resources to those most likely to benefit from them, to those who are seen as most deserving, to those who are seen as likely to make the greatest social contribution in the future, to those willing to pay the highest price for them, to those who have the greatest responsibility for nurturing the lives of others, to those likely to enjoy the highest quality of life, or through a random system of allocation such as a lottery.

In health care, a strong case can be made for following a policy that maximizes the number of lives saved. Of course these lives must be of minimal quality since merely maintaining biological function in a body is not a standard of quality of life that most people deem worthy of medical resources. The criteria used to determine rationing schemes must be linked to the effectiveness of the resource, because the same standards may not be appropriate when one is trying to decide who gets access to a resource known to save lives (e.g., heart transplants), as opposed to granting access to resources whose effectiveness is poor or uncertain (e.g., pancreas transplants, intestinal transplants, and lung transplants for children).

If a form of transplantation works, then it would seem that efficacy in the saving of a life should drive allocation. After all, those who give organs say they do so to save lives. Those who transplant say they do so to save lives. And the reason organ transplantation has special status as a noncommodity in Western societies is that the goal of making the gift of an organ available is to save lives. If the goal is to save lives then giving organs to the sickest persons who need them is not necessarily the best way to achieve this goal. In the future more attention must be paid to outcomes as well as need and urgency in transplant allocation policies in the United States and other nations (Reese and Caplan 2011).

The current set of criteria in the United States reflects a complex set of moral considerations including sensitivity to the need for efficacy shown in weighting biological factors and moving pediatric patients to the head of many organ waiting lists, fairness shown in giving preference for prior donation as well as to waiting time, justice in permitting some of those with no access in their home nations to enter the system from foreign nations, and deservedness in allowing the better off greater access through multiple listing and to wealthy foreigners who constitute the majority of non-U.S. recipients. Although much is made of the weight given to waiting time, no single value governs the current system of rationing.

Proponents of change in rationing criteria to give more weight to efficacy make their case based on the waste in lives and life years lost created by too much emphasis on waiting time (Reese et al. 2010; Hippen et al. 2011; Reese and Caplan 2011). To improve survival with a transplant, a system of rules weighted toward "survival matching" could be used. This means allocating the highest quality kidneys to the candidates with the highest estimated posttransplant survival and allocating the remaining organs so that candidates who are within 10-15 years, older or younger, of the donor's age receive the highest priority (Reese and Caplan 2011).

It is true that the current ability to forecast graft and recipient survival is far from perfect 
(Hippen et al. 2011). But, evidence for meaningful survival is not so deficient that it could not be invoked in a general way to help guide the more effective use of the scarce supply of organs. More to the point, criticism about the limits of current prognostication variables such as age or weight or comorbidity to predict who will do the best with a transplant does not meet the criticism that the system does not give sufficient weight to efficacy. It merely is an argument for more research toward obtaining evidence to achieve that end (Reese et al. 2010).

The case for moving toward greater efficacy in rationing makes ethical sense relative to distributing other scarce, valuable resources. In rationing situations saving the most lives and the greatest number of quality life years is a strategy that is followed in rescue scenarios or when facing public health emergencies (Reese et al. 2010). Giving the greatest weight to efficacy also seems consistent with what donors intend. Shifting toward efficacy defined as both increasing the odds of saving lives and saving the most life years, although not the exclusive value for rationing, would seem to make the most moral sense in confronting limited resources. Shifting public policy to expand those limited resources and minimize scarcity is a powerful requirement in any situation in which rationing exists, including transplantation.

\section{REFERENCES}

Abadie A, Gay S. 2006. The impact of presumed consent legislation on cadaveric organ donation: A cross-country study. J Health Econ 25: 599-620.

Byk C. 2009. The European protocol on organ transplant: Key issues. J Int Bioethique 20: 119-133.

Caplan AL. 1984. Organ procurement: It's not in the cards. Hastings Center Report October 14, pp. 6-9.

Caplan AL. 2004. Transplantation at any price? Am J Transplant 4: 1933-1934.

Caplan AL. 2013. It is not morally acceptable to buy and sell organs for human transplantation. In Contemporary de bates in bioethics (ed. Caplan AL, Arp R), pp. 59-67. Wiley Blackwell, Hoboken, NJ.

Caplan AL, Coehlo DH (ed.). 1998. The ethics of organ transplants. Prometheus, New York.
Caplan AL, Prior C. 2009. Trafficking in organs, tissues and cells and trafficking in human beings for the purpose of the removal of organs. Joint Council of Europe/United Nations Study, Strasbourg.

Caplan AL, Rockman HA, Turka LA. 2012. Editorial position on publishing articles on human organ transplantation. J Clin Invest 122: 2.

Chandler JA. 2005. Priority systems in the allocation of organs for transplant: Should we reward those who have previously agreed to donate? Health Law J 13: 99-138.

Davis FD, Crowe SJ. 2009. Organ markets and the ends of medicine. J Med Philos 34: 586-605.

DeVita M, Caplan AL. 2007. Caring for organs or for patients? Ethical concerns about the Uniform Anatomical Gift Act. Ann Intern Med 147: 876-879.

Hippen BE, Thistlethwaite JR, Ross LF. 2011. Risk, prognosis and unintended consequences in kidney allocation. $N$ Engl J Med 364: 1285-1287.

Hughes PM. 2009. Constraint, consent, and well-being in human kidney sales. J Med Philos 34: 606-631.

Jaycox MP. 2012. Coercion, autonomy, and the preferential option for the poor in the ethics of organ transplantation. Dev World Bioeth 12: 135-147.

Kerstein SJ. 2009. Autonomy, moral constraints, and markets in kidneys. J Med Philos 34: 573-585.

Lawlor R. 2011. Organ sales needn't be exploitative (but it matters if they are). Bioethics 25: 250-259.

Matas AJ. 2006. Why we should develop a regulated system of kidney sales: A call for action! Clin J Am Soc Nephrol 1: 1129-1132.

Neades BL. 2009. Presumed consent to organ donation in three European countries. Nurs Ethics 16: 267-282.

Quigley M, Wright L, Ravitsky V. 2012. Organ donation and priority points in Israel: An ethical analysis. Transplantation 93: 970-973.

Reese PP, Caplan AL. 2011. Better off living - the ethics of the new UNOS proposal for allocating kidneys for transplantation. Clin J Am Soc Nephrol 6: 2310-2312.

Reese PP, Caplan AL, Bloom RD, Abt PL, Karlawish JH. 2010. How should we use age to ration health care? Lessons from the case of kidney transplantation. JAm Geriatr Soc 58: 1980-1986.

Sanaei Ardekani M, Orlowski JM. 2010. Multiple listing in kidney transplantation. Am J Kidney Dis 55: 717-725.

Slabbert M. 2012. This is my kidney, I should be able to do with it what I want: Towards a legal framework for organ transplants in South Africa. Med Law 31: 617-640.

Tan HP, Marcos A, Shapiro R, ed. 2008. Living donor organ transplantation. McGraw Hill, New York.

Taylor JS. 2009. Autonomy and organ sales, revisited. J Med Philos 34: 632-648.

Veatch R. 2002. Transplantation ethics. Georgetown University Press, Washington, DC.

Wang M. 2010. Organ donation by capital prisoners in China: Reflections in Confucian ethics. J Med Philos 35: $197-$ 212. 


\section{$\&_{\mathrm{CSH}}^{\infty} \&$ Cold Spring Harbor

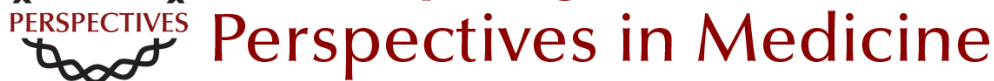

\section{Bioethics of Organ Transplantation}

Arthur Caplan

Cold Spring Harb Perspect Med 2014; doi: 10.1101/cshperspect.a015685 originally published online January 29, 2014

\section{Subject Collection Transplantation}

Heart Transplantation: Challenges Facing the Field

Makoto Tonsho, Sebastian Michel, Zain Ahmed, et al.

Bioethics of Organ Transplantation Arthur Caplan

Overview of Clinical Lung Transplantation Jonathan C. Yeung and Shaf Keshavjee

Immunological Challenges and Therapies in

Xenotransplantation Marta Vadori and Emanuele Cozzi

Clinical Aspects: Focusing on Key Unique

Organ-Specific Issues of Renal Transplantation Sindhu Chandran and Flavio Vincenti

T-Cell Costimulatory Blockade in Organ

Transplantation

Jonathan S. Maltzman and Laurence A. Turka

Regulatory T-Cell Therapy in Transplantation:

Moving to the Clinic

Qizhi Tang and Jeffrey A. Bluestone

Opportunistic Infections--Coming to the Limits of Immunosuppression?

Jay A. Fishman
Overview of the Indications and Contraindications for Liver Transplantation

Stefan Farkas, Christina Hackl and Hans Jürgen Schlitt

Facial and Hand Allotransplantation Bohdan Pomahac, Ryan M. Gobble and Stefan Schneeberger

Induction of Tolerance through Mixed Chimerism David H. Sachs, Tatsuo Kawai and Megan Sykes

Pancreas Transplantation: Solid Organ and Islet Shruti Mittal, Paul Johnson and Peter Friend

Tolerance--Is It Worth It?

Erik B. Finger, Terry B. Strom and Arthur J. Matas

Lessons and Limits of Mouse Models Anita S. Chong, Maria-Luisa Alegre, Michelle L. Miller, et al.

Effector Mechanisms of Rejection Aurélie Moreau, Emilie Varey, Ignacio Anegon, et al.

The Innate Immune System and Transplantation Conrad A. Farrar, Jerzy W. Kupiec-Weglinski and Steven H. Sacks

For additional articles in this collection, see http://perspectivesinmedicine.cshlp.org/cgi/collection/ 